\title{
Career Success and Its Predictors: Comparing between Canadian and Chinese
}

\author{
Chen $\mathrm{Yu}^{1}$ \\ ${ }^{1}$ Zhejiang Gongshang University, Zhejiang, China \\ Correspondence: Chen Yu, Zhejiang Gongshang University, Zhejiang, China. E-mail: yuchensf@163.com
}

Received: January 17, 2012 Accepted: June 11, 2012 Online Published: July 16, 2012

doi:10.5539/ijbm.v7n14p88 URL: http://dx.doi.org/10.5539/ijbm.v7n14p88

The research is sponsored by National Natural Science Foundation of China (70972135)

\begin{abstract}
Purpose-The purpose of this study was to investigate the difference between Canadian and Chinese about career success, and what are predictors of career in their eyes.

Design/Methodology-A sample of 121 employees in Canada and China is surveyed. Data analyses are used to test the hypotheses. Career success was measured by subjective, that is career satisfaction.

Findings-1) Career success can be measured by subjective feeling. 2) There are significant difference in career success between Canadian and Chinese. 3) There were three main predictors of career success, which were education, personality and perception of organizational support.

Implications-Knowledge of the different attitude on the predictors of career success between Canadian and Chinese should provide certain advantages to understand the culture of the two countries.

Originality/Value-This paper makes a valuable contribution to the career success literatures by investigating kinds of predictors of career success.
\end{abstract}

Keywords: career success, personality, independent sample T-test

\section{Introduction}

Many researchers have been interested in career success in the organizational management literature since 1980s. Career success is defined by Seibert \& Kraimer (2001) as the accumulated positive and good work and psychological outcomes (such as achievement, high salary and so on) resulting from individual work experiences. It improves individuals' quantity or quality of life, in fact, career success also is the perceived achievements, satisfaction and growth which came from the result of individual work experiences.

Career success is very important and meaningful to individuals and their organizations. At the employees' eyes, career success can be defined as not only source of power, happiness and satisfaction but also acquisition of materialistic advancement (Gattiker \& Larwood, 1990, 1988; Judge et al., 1995; Poole et al., 1991). Thus, employees who gain career success feel happier and more successful, using their own internal standards than those who do not gain. Knowledge of the method and predictors of career success can help employees to develop good strategies for career development and growth (Aryee et al., 1994; Ellis \& Heneman, 1990). In return, at the employer's level, employees' career development and growth can eventually improve organizational performance (Judge, Higgins, Thoresen, \& Barrick, 1999). Previous studies have also found that employees who are more satisfied with their careers can make more effectively contribute to the organization's performance (Peluchette, 1993; Harter, Schmidt and Hayes, 2002). Knowledge of the relationship between predictors and career success can help employer to design effective career systems and other career management policy.

Sociological research on the determinants of career success is quite extensive. Tharenou (1997) found several predictors of career success in a review of the career success literature. Human capital attributes (training, tenure, education) and demographic factors (age, sex, marital status, number of children) were most commonly investigated in previous research. These categories of determinants have provided important insights into the antecedents of career success, but there is also room for further study. Specifically, little previous research has examined all the factors together. 
Some researchers addressed the relationship between various predictors and career success, using relatively selective US samples with a narrow range of occupations (e.g. Boudreau et al., 2001; Judge et al., 1999; Seibert and Kraimer, 2001). As they discussed, the present study seeks to improve on these earlier studies. We analyze pooled cross-sectional data of China and Canada. We studied career success for the bigger range of culture and occupations by the nature of the 121 employees' sample.

The purpose of this research is to answer what is career success, what is the main predictors of career success and if there is significant difference in career success between Canadian and Chinese.

In spite of the importance and intuitive appeal of the concept of career success, there has been much less researchers paid attention to the difference between two cultures, in contrast with the much more frequently studied.

\section{Related Literature and Hypothesis}

We can define person's career as a sequence and process of education, training and work activities that are necessary to him or her, making more contribution to the organization in which he or she participates. Career is different from work. Take an example, some university students have a part-time job, they have work to make money, but they have no any career at that time, they study to get a good career. Therefore, job or work just for money or life, career is for more, including self-achieve, prestige and so on.

How to define career success? Is it high salary, position, promotions, status or other tangible outcomes? Is it an individual's psychological feeling of his/her career, such as work or career satisfaction, perceptions of career accomplishments? Abele and Wiese (2008) postulated three facets of career success, objective career success, subjective career success and comparison standard.

Career success has also been defined as objective and subjective elements of individual accomplishments and progress through the whole vocational lifespan. Career success has two kinds of aspects: extrinsic and intrinsic. Extrinsic success is relatively objective and tangible, and typically consists of highly visible outcomes such as salary, status (Jaskolka, Beyer, \& Trice, 1985) promotions, and/or position (Ng et al., 2005).Conversely, intrinsic success is looked as an individual's perception of his or her own career, and is most commonly investigated as career satisfaction (Gattiker \& Larwood, 1988; Judge et al., 1995). Employer might paid more attention to objective career success (e.g. an individual's achievements in terms of salary, position, promotions, and job performance), individuals might be especially care about subjective career success (e.g. positive career-related perception). By far, subjective career success has been more widely focused in previous literature than objective success. On the other hand, satisfaction with one's career is a standard for assessing the quality of one's career experiences.

Success should be an evaluative conception and the method of evaluation requires an outcome can be assessed. When research about success it is very important to decide what is criteria or indicator of success. The criteria mentioned must be objective and tangible to others. However, different position, industry, country and so on, there is no the same criteria, so, many researchers all looked career success as perceived achievements individuals have accumulated, from their work experiences (Judge et al., 1995).Subjective evaluation, examples of measures that have been used include satisfaction and vocational goals reached, can tap possible individual or cultural differences in feelings about these objective career.

Based upon the above, we develop hypothesis:

\section{H1: Samples think career success is individual's subjective reactions or feeling to his/her own career.}

Researchers from a wide variety of disciplines continue to investigate many psychological characteristics that could contribute to career success. For example, Thomas \& Daniel (2010) investigated the mediating processes through which human capital contribute to objective career success .Career choice (Gattiker \& Larwood, 1990), success criteria (Poole et al., 1991) are also some examples of more recent determinants of career success that have been investigated. Judge et al. (1995) surveyed 1400 executives in a diverse sample of U.S. organizations, finding that demographic, human capital, and motivational variables had important influences on career success. Kirchmeyer (1998) found supervisor support was positively related to managerial perceived career success.

H2: There were 12 main predictors of career success, they are education, personality and organizational support and so on.

A recent comparative study of nine countries found no differences in career success based on occupation or country and most demographic variables (Punnett, et al., 2007). In accord with this previous work, Noordin.et al. (2002) also found no significant differences between the two groups with regard to career identity and career 
planning commitment by another comparative study of Australian and Malaysian managers. But, understanding career success, there may be some difference in different culture. Canada is different from China. Therefore, a recent comparative study of career satisfaction found white/Caucasian employees were more satisfied with their careers than Black, South Asian and Chinese employees (Margaret, et al., 2010).

So, we develop hypothesis:

H3: There is significant difference in understanding career success and career success between Canadian and Chinese.

\section{Participants}

The data for this study were obtained from many kinds of companies between 121 Canadian and Chinese, such as, consulting company, high technology companies, university and so on. Job titles included managers (82\%), technology personnel (2\%), operator personnel (4\%), and other service personnel (12\%). Of the total sample, $48.8 \%$ were male and $51.2 \%$ were female. Relative frequencies by age group were: younger than $25,12.4 \% ; 26$ to $35,66.9 \% ; 36$ to $45,12.4 \%$, older $46,8.3 \%$. Relative frequencies by education group were: college, $8.2 \%$; university, $59.5 \%$; post-graduate, $22.3 \%$. Relative frequencies by marital status group were: single, $43 \%$; married, $52.9 \%$; divorce, $4.1 \%$.

\section{Variable Measurement}

Career success is defined as an individual's long term satisfaction with his/her career (Judge et al., 1995). Career success is also the satisfaction individuals derive from intrinsic and extrinsic aspects of their careers, including pay, advancement, status and career developmental opportunities (Judge et al., 1995).

Career success is an evaluative concept. Evaluation method requires a criteria judged by. Individual career success can use internalized aspirations and feelings that are not visible to others, the results of such judgments are relatively subjective internal states or feelings. In the study, career success is evaluated by subjective feelings, career satisfaction.

Career satisfaction was measured with the eight-item scale designed by Judge et al. (1999), which appears to be the best measure available in the previous literature. The eight items are: (a) I am satisfied with which work involves interests; (b) I am satisfied with my coworkers; (c) I am satisfied because I can use my skills and abilities on my work; (d) I am satisfied with supervision; (e) I am satisfied with respect that others give to job; (f) I am satisfied with ability to develop ideas on job; (g) Satisfaction with job security; (h) I am satisfied with my income from the job. Judge et al. (1999) reported an acceptable level of internal consistency for this scale (alpha $=.92$ ). In this study, the coefficient alpha reliability estimate was .89 .

\section{Result}

In the research survey, we asked response to let us know your opinion about career success. How much do you agree with each of the following statements: $5=$ strongly agree; $4=\mathrm{a}$ little agree; $3=\mathrm{I}$ am not sure; $2=$ Disagree; $1=$ strongly disagree.

What do you think career success is? Career success is: Individual's subjective reactions or feeling to his/her own career; Do the job without any problems/difficulties; Get along well with colleague and supervisor; Goal is achieved; Do the job he or she like, and is interested in the job; High salary and adequate promotions; Real or perceived achievements individuals have accumulated as a result of their work experience; Power and authority provided by the job.

Our analyses showed the opinion that subjective reaction is career success is popularly accepted.

Table 1. What is career success -focusing on all sample

\begin{tabular}{lccccc}
\hline & Sample & Max & Min & Mean & SD \\
\hline Subjective reactions & 121 & 2 & 5 & 4.33 & .80 \\
Without problems & 121 & 1 & 5 & 3.93 & .94 \\
Get along well & 121 & 1 & 5 & 4.04 & .87 \\
Goal is achieved & 121 & 1 & 5 & 4.26 & .84 \\
Like job & 121 & 1 & 5 & 4.21 & .88 \\
Achievements & 121 & 1 & 5 & 3.94 & .93 \\
High salary & 121 & 1 & 5 & 4.36 & .91 \\
Power & 121 & 1 & 5 & 3.28 & 1.1 \\
\hline
\end{tabular}


Table 2. What is career success -focusing on Canadian sample

\begin{tabular}{lccccc}
\hline & Sample & Max & Min & Mean & SD \\
\hline Subjective reactions & 47 & 2 & 5 & 4.32 & .88 \\
Without problems & 47 & 2 & 5 & 3.87 & 1.0 \\
Get along well & 47 & 2 & 5 & 4.02 & .84 \\
Goal is achieved & 47 & 1 & 5 & 4.28 & .90 \\
Like job & 47 & 2 & 5 & 4.43 & .80 \\
Achievements & 47 & 1 & 5 & 3.83 & 1.0 \\
High salary & 47 & 2 & 5 & 4.21 & .83 \\
Power & 47 & 1 & 5 & 2.94 & 1.1 \\
\hline
\end{tabular}

Table 3. What is career success -focusing on Chinese sample

\begin{tabular}{lccccc}
\hline & Sample & Max & Min & Mean & SD \\
\hline Subjective reactions & 71 & 2 & 5 & 4.35 & .69 \\
Without problems & 71 & 1 & 5 & 3.93 & .90 \\
Get along well & 71 & 1 & 5 & 4.03 & .89 \\
Goal is achieved & 71 & 1 & 5 & 4.25 & .80 \\
Like job & 71 & 1 & 5 & 4.06 & .92 \\
Achievements & 71 & 2 & 5 & 3.97 & .82 \\
High salary & 71 & 1 & 5 & 4.49 & .95 \\
Power & 71 & 1 & 5 & 3.44 & 1.1 \\
\hline
\end{tabular}

From the result, we know that "career success is high salary and adequate promotions" is the most popularly accepted. At the same time, the opinion that career success is individual's subjective reactions or feeling to his/her own career is very popularly accepted.

For Canadian and Chinese, there is some difference, for Canadian, career success is do the job he or she like, and is interested in the job, however, Chinese sample think high salary and adequate promotions. Career success is doing the job he/she likes is less accepted by Chinese.

Need to say, the opinion that career success is power and authority provided by the job is less accepted by Canadian.

Table 4. Difference between Canadian and Chinese on career success

\begin{tabular}{lcccc}
\hline & Sample & Mean & SD & Mean's SE \\
\hline China & 73 & 3.46 & 0.56 & 0.65 \\
Canada & 47 & 3.50 & 1.09 & 0.159 \\
\hline
\end{tabular}

According to nationality, the sample was divided into two groups, group1 was Canadian, the other group was Chinese, career success looked as dependent variable. Using one sample $T$ test, the result showed that there was significant difference between the two groups.

Table 5. Independent sample test

\begin{tabular}{|c|c|c|c|c|c|}
\hline \multirow[t]{3}{*}{ Career Success } & \multicolumn{5}{|c|}{ Levene's test for equality of variance } \\
\hline & \multicolumn{5}{|c|}{$95 \%$ confidence interval of the difference } \\
\hline & $F$ & Sig. & $t$ & lower & upper \\
\hline Equal variances assumed & 5.30 & .023 & -.215 & -.332 & .26 \\
\hline \multirow[t]{2}{*}{ Equal variances not assumed } & & & -.18 & -.376 & .31 \\
\hline & \multicolumn{2}{|c|}{ Mean difference } & $d f$ & \multicolumn{2}{|c|}{ Std error difference } \\
\hline Equal variances assumed & \multicolumn{2}{|c|}{-.032} & 118 & \multicolumn{2}{|c|}{.151} \\
\hline Equal variances not assumed & \multicolumn{2}{|c|}{-.032} & 61.84 & \multicolumn{2}{|c|}{.17} \\
\hline
\end{tabular}


You can see the results of the analysis in Table 5, the mean difference is obtained by subtracting the mean for group 2 from the mean for group 1. The sign of the mean difference dictated the sign of the $\mathrm{T}$ value. The negative $T$ value indicated that the mean amount of career success for group 2 (Canadian sample) is significantly greater than the mean for group 1 (Chinese sample).

There were plenty of research results about the predictors of career careers in vocational field. Ng et al. (2005) demonstrated the popularity of identifying key predictors of career success by analyzing over 140 studies conducted in 2002 or earlier.

We set 12 predictors (please see table 6) of career success and ask response to rank them by importance, 1 means the most important, 12 means the least important. So, we give each predictor a number indicating importance, if one predictor ranked the first by a response, it will get 12, if the predictor ranked the least by a response, it will get 1 , altogether the predictor will get a sum. Because the result is effected by number of response, therefore the result divided by $12 *$ number of sample, Canadian sample is $576(12 * 48)$, Chinese sample is $876(12 * 73)$.The value is near 1 , the bigger the value is, the more important the predictor is.

Proactive colleague and organizational support are most different, Chinese think it is very important, but Canadian does not think so.

Table 6. Importance of predictors of career success

\begin{tabular}{cccccccccccc}
\hline P & A & FS & WE & E & P & N & G & OS & L & PS & PC \\
\hline 0.79 & 0.50 & 0.69 & 0.87 & 0.77 & 0.7 & 0.35 & 0.4 & 0.77 & 0.63 & 0.34 & 0.5 \\
0.74 & 0.43 & 0.62 & 0.76 & 0.82 & 0.56 & 0.31 & 0.39 & 0.63 & 0.66 & 0.38 & 0.4
\end{tabular}

Note: $\mathrm{P}=$ Personality: friendly; $\mathrm{A}=$ Age; $\mathrm{FS}=$ Family support; WE=Work Experience; $\mathrm{E}=$ Education; $\mathrm{P}=$ Proactive colleague; $\mathrm{N}=$ Number of Children; $\mathrm{G}=\mathrm{Gender}$; $\mathrm{OS}=$ Organizational Support; $\mathrm{L}=$ English/French is good; $\mathrm{PS}=$ Parents' salary; $\mathrm{PC}=$ Parents' career success.

In a word, work experience, education and personality are both the most important predictors.

\section{Discussion}

This paper compares career success between Canadian and Chinese. We have investigated what is career success. Career success is individuals gained accomplishments or other positive psychological outcomes from his or her work experiences during the span of career life. Therefore, career success is subjective reactions is popular accepted by Canadian and Chinese.

What is career success? It has many answers, such as do the job he likes, high salary and so on. Our research found Canadian think do the job he likes is career success. Chinese think high salary is career success. It is different. It is well known that Canada's salary distance is small, China's salary distance is bigger.

Knowing the factors that affect career success can help individuals to design good and proper strategies for career growth, several such factors that have gained prominence in the literature on career subjective success are human capital, personality, workplace perceptions and demographic factors. Human capital theory supports that employees with more education and training experience will get higher salary than people received less education and work or training experience, therefore, education and work experience should be positively related to career success. We set 12 predictors (please see table 6) of career success, asking response to rank them by importance, the result is that education, personality and organizational support are the most important factors, which is in accord with previous research. Such as Barnett et al. (2007) conducted the relationship between organizational support for career development and employees' career satisfaction. Ballout (2007) also has shown supervisor support is significantly related to individual career satisfaction. Turban and Dougherty (1994) argued personality (including locus of control, self-monitoring, self-esteem, and negative affectivity) can forecast career success. Victor P. L and Margaret A. S. (1999) investigated that several personality traits, such as locus of control, self-monitoring, self-esteem along with job performance and person-environment fit are determinants of career success.

With challenges of today's continually changing work environment, knowledge employees should take charge of their careers because recently a rapid shift in the locus of responsibility for career success has been seen. For example, Murphy and Ensher (2001) found that individuals who can management their own career reported greater job satisfaction and perceived career success; those who engaged in positive cognitions also had higher 
job satisfaction. At the same time, employees should focus on their own career competence. Therefore, personality is the important predictor of career success.

Most previous studies have examined the differences on career satisfaction between white/Caucasian and racial minority employees (Greenhaus, Parasuraman and Wormley, 1990; Cox and Nkomo, 1991). This present study shows that Chinese were significantly less satisfied than Canadian.

\subsection{Implications of the Results}

According to Berg (1991) and Peluchette (1993) career satisfaction is not only related to performance and engagement but also linked to higher organizational commitment. Poon (2004) believed career satisfaction can improve individual creativity and innovational performance. Harter, Schmidt and Hayes (2002) also argued that there are linkages between career success and a number of business outcomes that are important to organizations, such as customer loyalty, profitability and lower employee turnover. At the same time, studies have shown that employees who are more satisfied with their careers are more engaged in job and thus they make more contribution to the organization than those who are less satisfied with their careers (Peluchette, 1993; Harter, Schmidt and Hayes, 2002). Our study also affirmed the career success is related to individual perception of achievement or good feeling from the job.

Today's organizations face increased competition. In this challenging environment, they should attract and retain the best possible employees can benefit from an understanding of what leads to their career success. Our findings have practical implications because it is beneficial to clarify the process by which career success is created could therefore allow organizations to attract applicants whose higher levels of career values, in turn, to be satisfied and committed to their job and career.

The most important contribution of this research is comparing between Canadian and Chinese about career success. The results of the study are particularly useful since they help us know more about the difference between the two nations.

\subsection{Limitations and Future Research Suggestions}

As with any study, the study should have certain limitations. This study has several particular limitations that should be noted.

Firstly, this study was limited by the set of factors that were proposed to be linked to career success. Although there are many predictors that have been examined in previous models of career success, the present study just set 12 factors which will not be investigated how they impact career success. Future research should explore additional information and explanation of these results. For example, more explanation is needed on the mechanisms through which 12 factors into career success.

Recent models of career success have included a number of individuals' variables. For example, Samuel, A. et al (1994) affirmed that the antecedent sets of human capital, work values, family and structural or work variables accounted for over $40 \%$ of the explained variance in career success. Poole et al. (1993) argued linkages between variables that define one's life context which are posited to impinge on one's subjective career success. However, the study did not really examine internal variables influencing career success. One area of future research should examine the influence of various internal variables on career success.

Secondly, one of limitations was the predominately Canadian and Chinese sample, which limited the generalizability of the results. That is, the sample was smaller than preferred and may have restricted the power needed to obtain significant results. Future research should attempt to replicate these results with larger, more diverse samples and develop process models that may explain why and how 12 predictors influence on career success.

Third, we were not able to focus on the moderators for some relationships because the information is not sufficient. Future research should explore moderators for these relationships in this study.

Career success can be evaluated subjectively or objectively. The study did not identify what are the different types of career success. Future research should examine objective or both.

Admittedly, the implications presented are speculative but realistic. However, from a managerial standpoint, future research needs to move beyond the current status quo and explore these important issues.

\section{Conclusion}

The purpose of this study was to investigate the difference between Canada and China about career success, and what are predictors of career success in their eyes. Survey data were collected from a sample of 121 employees 
from Canada and China. Our data show that career success was measured by subjective, that is career satisfaction. The study found 3 points, (1) Career success can be measured by subjective feeling. That is, career success is individual's subjective reactions or feeling to his/her own career is most popularly accepted. (2) There are significant difference in career success between Canadian and Chinese. Canadian were significantly more satisfied than Chinese. (3) There were three most important predictors of career success in 12 predictors. This study also contributes to career research.

\section{References}

Abele, A. E., \& Wiese, B. S. (2008). Self-management: The nomological network of self-management strategies and career success. Journal of Occupational and Organizational Psychology, 81, 733-749. http://dx.doi.org/10.1348/096317907X256726

Aryee, S., Chay, Y. W., \& Chew, J. (1994). An investigation of the predictors and outcomes of career commitment in three career stages. Journal of Vocational Behavior, 44(1), 1-16. http://dx.doi.org/10.1006/jvbe.1994.1001

Ballout, H. I. (2007). Career success: the effects of human capital, person-environment fit and organizational support. Journal of Managerial Psychology, 22(8), 741-765. http://dx.doi.org/10.1108/02683940710837705

Barnett, B. R., \& Bradley, Lisa M. (2007). The Impact of organizational support for career development on $\begin{array}{lllll}\text { career satisfaction. Career Development International, } & \text { 7, 617-636. }\end{array}$ http://dx.doi.org/10.1108/13620430710834396

Berg, T. R. (1991). The Importance of Equity Perception and Job Satisfaction in Predicting Employee Intent to Stay at Television Stations. Group and Organization Studies, 16(3), 268-284. http://dx.doi.org/10.1177/105960119101600303

Boudreau, J. W., Boswell, W. R., \& Judge, T. A. (2001). Effects of personality on executive career success in the United States and Europe. Journal of Vocational Behavior, 58(1), 53-81. http://dx.doi.org/10.1006/jvbe.2000.1755

Cox, T. H., \& S. M. Nkomo. (1991). A Race and Gender-group Analysis of the Early Career Experience of MBAs. Work and Occupations, 18(4), 431-447. http://dx.doi.org/10.1177/0730888491018004004

Ellis, R., \& Heneman, H. G. (1990). Career pattern determinants of career success for mature managers. Journal of Business and Psychology, 5, 2-24. http://dx.doi.org/10.1007/BF01013942

Gattiker, U. E., \& Larwood, L. (1990). Predictors for career achievement in the corporate hierarchy. Human Relations, 43, 703-726. http://dx.doi.org/10.1177/001872679004300801

Greenhaus, J. H., Parasuraman, S., \& Wormley, W. M. (1990). Effects of Race on Organizational Experiences, Job Performance Evaluations and Career Outcomes. Academy of Management Journal, 33(1), 64-86. http://dx.doi.org/10.2307/256352

Harter, J. K., Schmidt, F. L., \& Hayes, T. L. (2002). Business-unit-level Relationship between Employee Satisfaction, Employee Engagement, and Business Outcomes: A Meta-analysis. Journal of Applied Psychology, 87(2), 268-279. http://dx.doi.org/10.1037/0021-9010.87.2.268

Jaskolka G., Beyer, J. M., \& Ti-ice H. M. (1985). Measuring and predicting managerial success. Journal of Vocational Behavior, 26, 189-205. http://dx.doi.org/10.1016/0001-8791(85)90018-1

Judge, T. A., Cable, D. M., Boudreau, J. W., \& Bretz, R. D. (1995). An empirical investigation of the predictors $\begin{array}{llll}\text { of executive career success. Personnel Psychology, 48, 485-519. } & \text {. }\end{array}$ http://dx.doi.org/10.1111/j.1744-6570.1995.tb01767.x

Judge, T. A., Higgins, C. A., Thoresen, C. J., \& Barrick, M. R. (1999). The Big Five personality traits, general mental ability, and career success across the life span. Personnel Psychology, 52, 621-651. http://dx.doi.org/10.1111/j.1744-6570.1999.tb00174.x

Kirchmeyer, C. (1998). Determinants of Managerial Career Success: Evidence and Explanation of Male/Female Differences. Journal of Management, 24(6), 673-692.

Margaret, Y., Wendy, C., Mark, R. H., \& Charity-Ann, H. (2010). Career Satisfaction: A Look behind the Races. Relations industrielles, 65(4), 584-609. 
Murphy, S. E., \& Ensher, E. A. (2001). The role of mentoring support and self-management strategies on reported career outcomes. Journal of Career Development, 27, 229-246. http://dx.doi.org/10.1023/A:1007866919494

Ng, T. W. H., Eby, L. T., Sorensen, K. L., \& Feldman, D. C. (2005). Predictors of objective and subjective career $\begin{array}{lllll}\text { success: A } & \text { A meta-analysis. Personnel }\end{array}$ http://dx.doi.org/10.1111/j.1744-6570.2005.00515.x

Noordin, F., Williams, T., \& Zimmer, C. (2002). Career commitment in collectivist and individualist cultures: a comparative study. International Journal of Human Resource Management, 13(1), 35-54. http://dx.doi.org/10.1080/09585190110092785

Peluchette, J. (1993). Subjective Career Success: The Infuence of Individual Difference, Family and Organizational Variables. Journal of Vocational Behavior, 43(2), 198-208. http://dx.doi.org/10.1006/jvbe.1993.1042

Poole, M., Langanfox, J., \& Omodei, M. (1991). Sex-difference in perceived career success. Genetic Social And General Psychology Monographs, 117(2), 153-178.

Poole, M., Langanfox, J., \& Omodei, M. (1993). Contrasting subjective and objective criteria as determinants of perceived career success: A longitudinal study. Journal of Occupational and Organizational Psychology, 66, 39-54. http://dx.doi.org/10.1111/j.2044-8325.1993.tb00515.x

Poon, J. (2004). Career commitment and career success: moderating role of emotion perception. Career Development International, 9(4), 374-390. http://dx.doi.org/10.1108/13620430410544337

Punnett, B. J., Duffy, J. A., Fox, S., Gregory, A., Lituchy, T.,... Miller, J. (2007). Career success and satisfaction: a comparative study in nine countries. Women in Management Review, 22(5), 371-390. http://dx.doi.org/10.1108/09649420710761446

Samuel, A., Wah, C. Y., \& Hoon, T. H. (1994). An examination of the antecedents of subjective career success among a managerial sample in Singapore. Human Relations, 47(5), 487-510. http://dx.doi.org/10.1177/001872679404700502

Seibert, S. E., \& Kraimer M. L. (2001). The five-factor model of personality and career success. Journal of Vocational Behavior, 58, 1-21. http://dx.doi.org/10.1006/jvbe.2000.1757

Seibert, S. E., \& Kraimer, M. L. (2001). Proactive personality indirectly relates to career progression and satisfaction through specific proactive behaviors and cognitive processes. Personnel Psychology, 54, 845-874. http://dx.doi.org/10.1111/j.1744-6570.2001.tb00234.x

Seibert, S. E., Crant, J. M., \& Kramier, M. L. (1999). Proactive personality and career success. Journal of Applied Psychology, 84, 416-427. http://dx.doi.org/10.1037/0021-9010.84.3.416

Tharenou, P. (1997). Explanations of managerial career advancement. International Review of Industrial and Organizational Psychology, 12, 39-93.

Thomas, W. H., \& Daniel, C. F. (2010). Human capital and objective indicators of career success: The mediating effects of cognitive ability and conscientiousness. Journal of Occupational and Organizational Psychology, 83, 207-235. http://dx.doi.org/10.1348/096317909X414584

Turban, D., \& Dougherty, T. (1994). Role of protégé's personality in receipt of mentoring and career success. Academy of Management Journal, 37(4), 688-702. http://dx.doi.org/10.2307/256706

Victor, P. L., \& Margaret, A. S. (1999). Career success: the effects of personality. Career Development International, 4(4), 225-230. http://dx.doi.org/10.1108/13620439910270607 